\title{
Memórias fraturadas: passado, identidade e imaginação em Borges e Mutarelli Pedro Galas Araújo
}

\author{
A permanência prometida pela pedra do monumento está sempre erguida \\ sobre a areia movediça. \\ Andreas Huyssen
}

A identidade de um indivíduo, e também a de uma coletividade, é constituída a partir de suas rememorações. É a lembrança que organiza e dá sentido ao presente, e é por meio dela que projetamos nosso futuro, visualizando possibilidades a partir de nossas experiências pregressas. Porém, a memória é falha, omissa, escorregadia, suspeita: muitas vezes, ela é conveniente, e não imparcial. Como então se fiar em terreno tão instável para alicerçar a própria subjetividade e entendê-la?

Nas últimas décadas, temos presenciado um recorrente apelo ao passado como elemento unificador da experiência pessoal e coletiva, isto é, como algo que dê sentido e coerência ao nosso presente, mas também que nos dê a sensação de que nos movemos no tempo, em direção a algum lugar. Vem daí a crescente museificação da identidade, erigida não só em monumentos públicos e memoriais, mas também na crescente oferta de romances históricos e autobiográficos; de narrativas em primeira pessoa que colocam o eu em evidência e, ao mesmo tempo, em questão; de vídeos e documentários que registram a experiência comum, perpetuada em imagens.

Nesse âmbito, o diálogo entre os textos "O outro", do argentino Jorge Luis Borges, e A caixa de areia ou eu era dois em meu quintal, do brasileiro Lourenço Mutarelli, pode iluminar a questão, na medida em que os dois, cada um à sua maneira, oferecem narrativas que discutem o papel da memória na formação da subjetividade do indivíduo - tanto como um ponto de partida, isto é, o alicerce onde se ajuntam as experiências que definirão, para o bem e para o mal, o caráter e a personalidade do sujeito, quanto como um elemento problemático, tortuoso, falho, que supre eventuais lacunas com artifícios da imaginação a fim de completar o todo e, por fim, dar sentido ao presente.

Em "O outro", Borges narra o encontro entre ele mesmo, já velho, e sua versão mais jovem: é o motivo para que se estabeleça o conflito entre o que se planejou ser e o que se lembra ter sido, com todas as suas nuances e desvios. Mutarelli, por sua vez, faz aparecer na caixa do gato os 
brinquedos da infância, elemento catalisador de uma crise de identidade que o leva a questionar também a própria noção de realidade como algo palpável, exterior, independente do ponto de vista do sujeito-observador. As duas situações insólitas promovem uma indagação em cada um dos personagens: em que medida eu posso falar de meu passado, se não me lembro de tudo e se não me reconheço no que lembro? As duas narrativas trabalham sobre os desvãos da memória, discutindo em que medida a identidade do indivíduo se sustenta na lembrança para se projetar para o futuro, mas, ao mesmo tempo, problematizam essa memória como depositário de certezas.

"Meu sonho já durou setenta anos. Afinal de contas, ao rememorar, não há pessoa que não se encontre consigo mesma. É o que está nos acontecendo agora, só que somos dois" (Borges, 2001, p. 10), diz o narrador de Jorge Luis Borges no conto "O outro", que narra o encontro do personagem homônimo do escritor com sua versão mais nova, ainda estudante, em uma praça em Genebra. A insólita reunião entre os dois vai da estranheza à aceitação, não sem uma certa melancolia: o jovem Jorge Luis porque não aceita sua imagem idosa, destituída de belos ideais, e o velho Borges porque reconhece sua decrepitude enquanto vê o tempo perdido com ingenuidades. O resultado, porém, é amargo: nem um nem outro podem mudar nem o que foram, nem o que se tornarão. São as experiências combinadas que compõem a identidade do indivíduo, são elas que o fazem ser quem é. Mas o peso do encontro é ainda mais doloroso para o Borges já idoso: "O encontro foi real, mas o outro conversou comigo em um sonho e foi assim que pôde esquecer-me; eu conversei com ele na vigília e ainda me atormenta a lembrança" (id., p. 16), encerra o narrador.

Os momentos finais do conto de Borges marcam a distinção entre idealização e realidade, entre projeção e memória, entre presente e passado. $\mathrm{O}$ jovem estudante sonhou o encontro, imaginou-o; o velho escritor viveu, acordado, o evento: não pode, portanto, desvencilhar-se do terrível contraste nem do peso da memória.

O personagem de Borges não buscou o encontro: ocorreu-lhe naturalmente. Mas, a partir dele, buscou compreender o presente, tentando entender as discrepâncias entre o que foi e o que se tornou. Esse retorno ao passado realizado pelo narrador está de acordo com o que Andreas Huyssen diz sobre o nosso tempo, marcado, mais precisamente a partir da segunda metade do século $X X$, por um constante reavivamento do passado, pelo despontar de uma cultura da memória, estimulada por "uma crescente instabilidade do tempo e pelo fraturamento do espaço vivido" 
(Huyssen, 2000, p. 20), provocados, entre outros fatores, pela sobrecarga de informações e pelo avanço tecnológico.

Ao mesmo tempo, as transformações na cultura global recorrentemente apontadas como definidoras da pós-modernidade, como "o fim da história, a morte do sujeito, o fim da obra de arte, o fim das metanarrativas" (id., p. 10), além de gerarem um interesse por outras tradições culturais, também nos trouxeram, em conjunto com as grandes catástrofes do século XX, uma profunda descrença no futuro, o que nos motiva a nos voltarmos, como consequência, ao passado, a fim de darmos coerência para nossa experiência e também para termos algum conforto diante de um futuro nebuloso, obscuro.

Segundo ele,

a questão, no entanto, não é a perda de alguma idade de ouro de estabilidade e permanência. Trata-se mais de uma tentativa, na medida em que encaramos o próprio processo real de compressão do espaço-tempo, de garantir alguma continuidade dentro do tempo, para propiciar alguma extensão do espaço vivido dentro do qual possamos respirar e nos mover. (id., p. 30)

Nesse cenário, Huyssen aponta que atrelado a essa "cultura da memória" está um abominável medo do esquecimento. Em uma sociedade que cada vez mais se volta para o passado e que valoriza a memória como elemento de guarida frente a um presente e a um futuro instáveis, Huyssen questiona se não seria o medo de esquecer que levaria ao desejo de lembrar ou se, pelo contrário, seria o excesso de memória que levaria à saturação esse sistema, gerando, assim, o medo do esquecimento (id., p. 19). De uma forma ou de outra, é notável a crescente cultura do passado que nos seduz com seu irresistível apelo, também comercial, de permanência e continuidade, desdobrando-se, entre outros exemplos, na "obsessiva automusealização através da câmera de vídeo, a literatura memorialística e confessional, o crescimento dos romances autobiográficos pós-modernos (com as suas difíceis negociações entre fato e ficção)" (id., p. 14). Isso sem contar, é claro, com a própria linguagem da informática, que avalia tudo em termos de "arquivamento de dados" e capacidade de "memória". De acordo com Pierre Nora, "fala-se tanto de memória porque ela não existe mais" (Nora, 1993, p. 7).

Beatriz Sarlo pensa de modo semelhante a Huyssen. Para ela, nosso tempo é caracterizado por uma necessidade urgente de se ter mais imagens. Mais que isso, parece haver a obrigação de que elas sigam umas às outras velozmente, se refletindo e se atropelando (Sarlo, 2005, p. 95). Isso fez com que o tempo, hoje, se tornasse mais fluido - a aceleração na 
duração das imagens afeta, por conseguinte, a memória e a lembrança: "o presente, ameaçado pelo desgaste da aceleração, converte-se, enquanto transcorre, em matéria de memória" (id., p. 95).

Para ela,

a aceleração produz, exatamente, um vazio de passado que as operações da memória tentam compensar. O novo milênio começa nesta contradição entre um tempo acelerado, que impede o transcorrer do presente, e uma memória que procura tornar sólido esse presente fulminante que desaparece devorando-se a si próprio. Recorremos a imagens de um passado que são, cada vez mais, imagens daquilo que é recente. Para sintetizar: trata-se de uma cultura da velocidade e da nostalgia, do esquecimento e da comemoração de aniversários. (id., p. 96)

Borges publicou "O outro", conto presente em O livro de areia, em 1975. É possível que parte das questões acima ainda fossem incipientes, que ainda não estivessem de todo desenhadas. Mas sua narrativa sobre o encontro fantástico, situado entre o sonho e a realidade, mesmo que seu personagem não recorra deliberadamente ao passado, já permite entrever o que se consolidaria anos mais tarde. Tal situação será vista em $A$ caixa de areia ou eu era dois em meu quintal, de Lourenço Mutarelli, em que outro acontecimento insólito permite o encontro com o passado e o consequente questionamento da identidade do personagem: repentinamente, começam a surgir, na caixa de areia do gato, brinquedos do personagem, enterrados, escondidos e perdidos quando ele ainda era criança, há quase 40 anos.

No livro, uma narrativa em quadrinhos, Mutarelli se apresenta como personagem da própria vida: os traços utilizados pelo desenhista são realistas, sem exageros, imprimindo um tom natural aos quadros. Uma foto de sua família reunida na última página permite a comparação: não é uma versão do personagem, seu alter ego, mas ele mesmo atuando, juntamente com seu filho e com sua esposa. Sua intenção com o livro, como diz em um dos quadrinhos, é fazer "um trabalho quase científico": "Estou buscando compreender a realidade" (Mutarelli, 2005, p. 83), diz. A metalinguagem não neutraliza o efeito; pelo contrário, o potencializa, e contribuem para isso as imagens que mostram os "bastidores" do processo de criação, com entrevistas gravadas e depois reproduzidas enquanto o artista trabalha (fig. 1), assim como o diálogo com o amigo Cláudio, em que reproduz, no quadrinho específico da conversa, toda a página na qual o próprio quadrinho está inserido (fig. 2). 

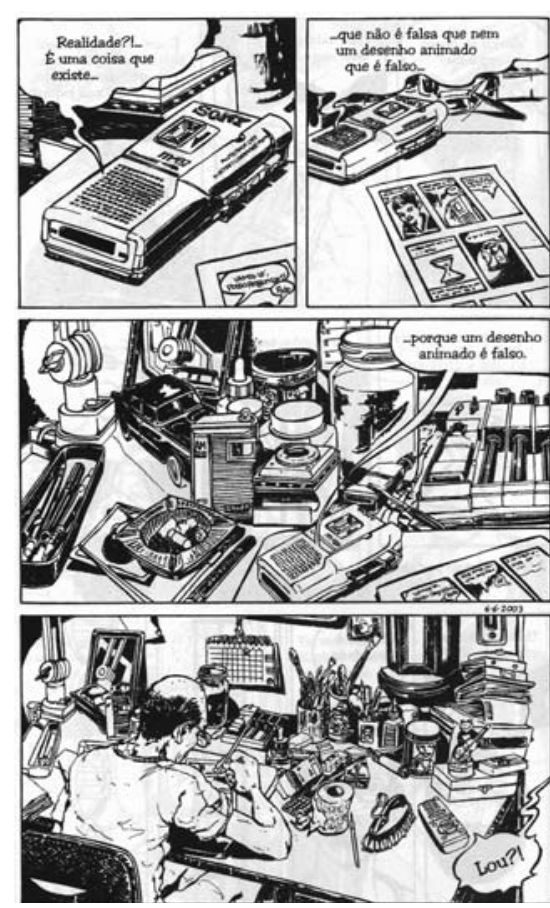

Fig. 1 - Mutarelli. A caixa de areia ou eu era dois em meu quintal, p. 46.
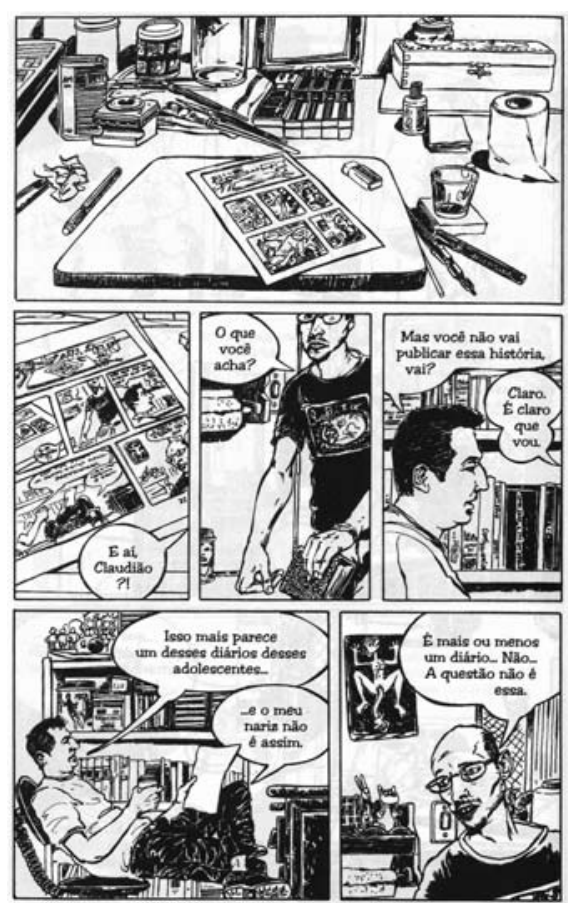

Fig. 2 - Mutarelli. A caixa de areia ou eu era dois em meu quintal, p. 82.

Essa aparente veracidade do relato, no entanto, é constantemente posta à prova: a página que abre o livro imita um panfleto de apresentação teatral, um espetáculo do "Teatro de Nanquim" (fig. 3), com o próprio Mutarelli travestido de gato. É um aviso prévio: estamos no terreno da invenção. A narrativa, instada de incertezas e insegurança, é constantemente colocada em questão. Apesar da minúcia do desenho e da presença da esposa e do filho do autor, que servem para dar crédito à história, cada aparição de um novo brinquedo desestabiliza a narrativa: a realidade não é o que parece, nem o relato pode ser tomado como verídico. 


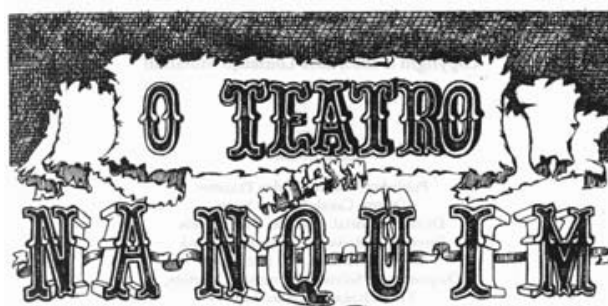

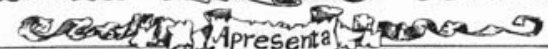

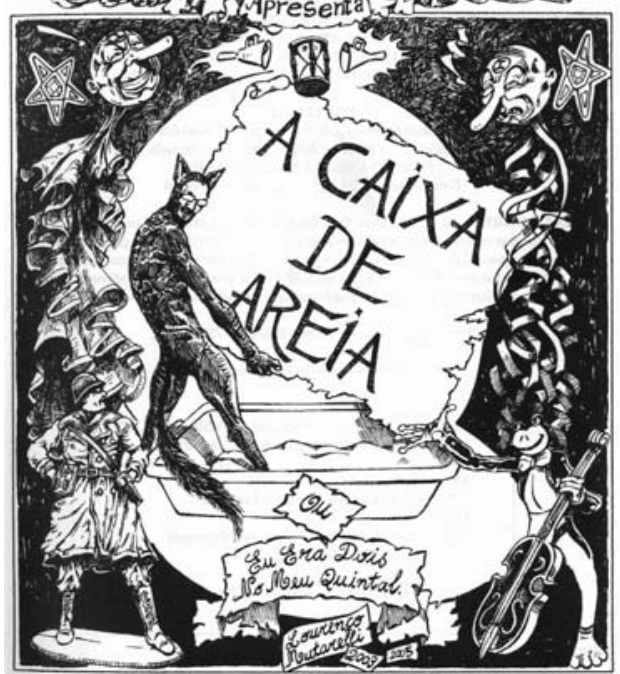

Fig. 3 - Mutarelli. A caixa de areia ou eu era dois em meu quintal, p. 4

Esses detalhes terminam por questionar a legitimidade atribuída à narrativa em primeira pessoa, sobretudo àquela em que o personagem se identifica explicitamente como o autor, usando seu nome. Para Philippe Lejeune, a identidade de nomes entre autor e personagem seria suficiente para que o leitor reconheça que o texto é uma narrativa autobiográfica. Mais que isso, essa consonância de nomes garante também a veracidade do relato: o autor empenha seu nome verdadeiro - logo, estaria sujeito a punições jurídicas e, por outro lado, não haveria por que mentir sobre a própria vida - na garantia de verdade do que é narrado.

Mas na narrativa de Lourenço Mutarelli, o surgimento repentino dos brinquedos da infância instaura um desequilíbrio, um descompasso no autor-personagem, que passa a se repensar enquanto sujeito, indagando sobre sua própria subjetividade, sobre sua memória, e esse desarranjo é transmitido para a narrativa, mas também para o leitor, que começa então a desconfiar dos índices que garantem a verossimilhança da trama. 
Como acontece no conto de Borges, as consequências desse súbito reencontro com o passado, representado pela aparição dos brinquedos, não são puramente positivas: elas trazem também um inevitável questionamento sobre a realidade e sobre a identidade do próprio indivíduo. $\mathrm{O}$ personagem Mutarelli mais e mais se atormenta para tentar compreender o porquê desse repentino acontecimento, formulando hipóteses para justificar seu encontro com o passado: "Eu pensei em comprar alguns brinquedos e enterrá-los na caixa de areia. Para mandar ao pequeno náufrago da minha infância do meu quintal" (Mutarelli, 2005, p. 125), diz. Mas o que lhe resta é o sentimento de fracasso, de impossibilidade, tanto do projeto de um livro que registrasse a realidade, quanto da tentativa de entender a si mesmo a partir da memória: "Se eu fotografar o meu cotidiano, as fotos não passarão de uma mera representação. Até mesmo as palavras, ou os desenhos... Tudo não passa de representação" (id., p. 126). E aqui, mais uma vez, instaura-se a dúvida: a desconfiança sobre si mesmo e sobre a realidade desdobra-se na instabilidade do relato, e essa imprecisão é partilhada com o leitor.

Essas minúcias que problematizam as noções de referência, da memória e da identidade estão relacionadas com o que Beatriz Sarlo identifica como uma "guinada subjetiva": um rearranjo ideológico e conceitual que restabelece a razão do sujeito como prerrogativa dos estudos culturais e sociológicos. Para ela, o crescente apelo à memória está atrelado a uma "tendência acadêmica e do mercado de bens simbólicos que se propõe a reconstituir a textura da vida e a verdade abrigadas na rememoração da experiência, a revalorização da primeira pessoa como ponto de vista, a reivindicação de uma dimensão subjetiva" (Sarlo, 2007, p. 18). Daí que proliferem, atualmente, narrativas em primeira pessoa e romances históricos e autobiográficos: a valorização do sujeito implica também um apreço por sua história - por sua memória, pelo seu passado. A questão que Sarlo coloca é: como é possível atestar a veracidade de um relato pessoal, de um testemunho, se sua legitimidade se encontra na esfera pública, ou seja, na representatividade que o narrador ganhou em função de sua história como vítima - em sua análise, a autora aborda sobretudo os relatos de sobreviventes dos regimes totalitários -, mas se ampara em um terreno tão frágil como a memória?

Conforme diz Sarlo, a respeito dessa proliferação de relatos em primeira pessoa como um depositório privilegiado de memórias que não seriam acessíveis se não fossem os relatos testemunhais: "Já não é possível prescindir de seu registro, mas também não se pode deixar de problematizálo. A própria ideia de verdade é um problema" (id., p. 117). 
Apesar de a própria obra de Mutarelli colocar em xeque sua suposta "veracidade", tanto ao mostrar os bastidores da criação quanto a porosidade da memória na qual se fia, ainda assim trata-se de um livro que está afeito à "cultura da memória" de Huyssen e aos argumentos sobre a "guinada subjetiva" e o constante retorno ao passado que são as marcas da nossa época. Para Beatriz Sarlo, ao mesmo tempo em que temos a impressão de que há um constante apreço pelo instante, há, por outro lado, uma tendência à rememoração, à museificação. Mesmo a "história de massas" (e, junto com ela, os romances históricos), simplificada para se tornar produto consumível, tem sua razão de ser: ela "impõe unidade sobre as descontinuidades, oferecendo uma 'linha do tempo' consolidada em seus nós e desenlaces" (id., p. 14). Ou seja, nos reportamos ao passado, recorremos a ele para tornar mais coerente o nosso próprio tempo, tão fraturado e carente de sentido: "Esses modos da história res-pondem à insegurança perturbadora causada pelo passado na ausência de um princípio explicativo forte e com capacidade inclusiva" (id., p. 15).

Tanto em Borges quanto em Mutarelli esse passado aparentemente capaz de reorganizar o presente subitamente irrompe, pelo fantástico, no cotidiano. Nenhum dos dois o procurou: ele simplesmente surge, se materializa no presente, e nele é vivido. Beatriz Sarlo diz que o passado está sempre por perto, surgindo quando menos se espera "como a nuvem insidiosa que ronda o fato do qual não se quer ou não se pode lembrar" (id., p. 9).

Nenhum dos dois personagens parece ter algo a esconder, nenhum deles parece carregar uma culpa ou um trauma não revelados. $O$ passado neles assoma como um ato involuntário, natural, cujas consequências, ao invés de iluminarem o presente, são perturbadoras. O velho Borges reconhece, não sem nostalgia, mas também com certa impaciência, o desencanto com o mundo em contraste com os ideais juvenis: "Tua massa de oprimidos e párias - respondi - é apenas uma abstração. Só os indivíduos existem, se é que existe alguém" (Borges, 2001, p. 12), responde ao seu jovem interlocutor, a respeito da sonhada fraternidade entre os homens; Mutarelli, obcecado com a aparição dos brinquedos, ouve sua mulher perguntar se está tomando os remédios (Mutarelli, 2005, p. 104) e dizer que precisa descansar (id., p. 125): está ficando louco. Mas nem um nem outro conseguem se desfazer da lembrança, o que a torna ainda mais incômoda, obrigando-os a conviver com ela no presente, tentando dar-lhe sentido, especialmente no caso de Mutarelli, a partir dessa rememoração. Conforme coloca Beatriz Sarlo, "não se prescinde do passado pelo exercício da decisão nem da inteligência; tampouco ele é convocado por um 
simples ato de vontade. O retorno do passado nem sempre é um momento libertador da lembrança, mas um advento, uma captura do presente" (Sarlo, 2007, p. 9).

Outro conto de Jorge Luis Borges, "Funes, o memorioso", pode entrar nessa discussão, a despeito do próprio autor tê-lo descrito como uma "vasta metáfora da insônia" (Borges, 1998, p. 537), e não como uma narrativa sobre a memória. Nele, Borges nos apresenta um personagem que, depois de um acidente, torna-se incapaz de esquecer o mais insignificante dos detalhes: "Sabia as formas das nuvens austrais do amanhecer do trinta de abril de mil oitocentos e oitenta e dois e podia compará-las na lembrança aos veios de um livro encadernado em couro que vira somente uma vez..." (id., p. 543). Era capaz de reconstituir, pela lembrança, um dia inteiro: a tarefa consumia-lhe outro dia. "Funes não só recordava cada folha de cada árvore de cada monte, como também cada uma das vezes que a tinha percebido ou imaginado" (id., p. 544). Preso às mais ínfimas lembranças, Funes era, paradoxalmente, um ser estático no tempo: $o$ acidente o deixou aleijado, prostrado em cima de uma cama. O que lhe resta, inválido, é lembrar. Mas o passado, desta vez, não explica nem dá sentido ao presente: ele é um refúgio, mas é também uma danação. Funes era, por isso, ao mesmo tempo um afortunado e alguém que vive uma maldição, preso nos meandros da memória perfeita, incapaz de abstrair, de generalizar, de raciocinar. Por isso quase não dormia: a observação de qualquer objeto o tornava único, e era preciso que se voltasse para o único ponto que ainda não conhecia, uma paisagem distante, para que obtivesse algum sossego. De acordo com o neurocientista Iván Izquierdo, o esquecimento protege o nosso cérebro da saturação, do desgaste. No conto de Borges, esquecer é um requisito para pensar, que exige generalizações. Mas Funes não obteve benefício algum com sua memória prodigiosa: na verdade, transformou-se em um ser neutralizado por essa memória. Esquecer, então, nos impede de "naufragar em meio às próprias recordações" (Izquierdo, 2004, p. 97).

É curioso que o narrador de Borges diga que Irineu Funes "era o solitário e lúcido espectador de um mundo multiforme, instantâneo e quase intoleravelmente exato" (Borges, 1998, p. 545), ou que "no abarrotado mundo de Funes não havia senão pormenores, quase imediatos" (id., ibid.): parece descrever o nosso tempo, que, no dizer de Beatriz Sarlo, é superlotado de instantes, flashes do presente, onde proliferam informações - ao mesmo tempo em que há um constante apelo ao passado. Mas, no caso de Funes, o passado não surge como recurso para dar sentido ao presente, nem para tornar a experiência mais coerente: ele mesmo se 
presentifica, suplantando o momento atual - que Funes não vive, preso à cama.

Borges parece sugerir que prender-se ao passado, ter a lembrança perfeita impossibilita que se viva o presente: é a tensão entre um e outro que dá coerência ao vivido, e que, por fim, se projeta para o futuro. Em Caixa de areia ou eu era dois em meu quintal, Lourenço Mutarelli (2005, p. 105), o personagem, reconhece a impossibilidade da memória total: "Será que o passado é o que nós lembramos?", pergunta à esposa. Mas é ele mesmo quem responde: "A 'minha' história não existe. A 'minha' história eu crio e conto a mim mesmo. O indivíduo é uma ilusão" (id., p. 106).

Neste caso, a indagação sobre a memória e seus limites leva também ao questionamento da própria identidade: em que medida posso afirmar quem sou, se minha identidade se constitui também a partir da memória, e ela se revela falha, fraturada, omissa, seletiva? Conforme diz Pierre Nora, "porque é afetiva e mágica, a memória não se acomoda a detalhes que a confortam; ela se alimenta de lembranças vagas, telescópicas, globais ou flutuantes, particulares e simbólicas, sensível a todas as transferências, cenas, censura ou projeções" (Nora, 1993, p. 9).

Logo, como diz Márcio Seligmann-Silva, "se nossas ações são garantidas apenas por traços de memória, inscritos na nossa mente e na memória da nossa coletividade, como podemos ter uma garantia quanto à verdadeira identidade/história de cada um?" (Seligmann-Silva, 2005, p. 112). Se temos a ilusão de que somos inteiros, plenos, e não fracionados, é porque construímos, por meio da narrativa, uma identidade coerente, e preenchemos as lacunas da memória com a imaginação. Mesmo porque, conforme diz Paula Sibilia, "com esse apavorante esquecimento, quase sempre se esfacela a identidade do sujeito: perde-se aquilo que se é" (Sibilia, 2008, p. 130). Daí que recorramos à imaginação para suprir os vazios de nossa memória.

No filme Valsa com Bashir, o diretor Ari Folman também discute as brechas da memória e procura recuperar os fragmentos de suas lembranças quando combateu na Guerra do Líbano, mais especificamente os eventos traumáticos dos massacres de Sabra e Chatila. Em sua busca, reencontra um velho amigo, que relata uma história em que pacientes de um experimento psicológico foram submetidos à observação de dez imagens de sua infância, sendo que uma delas era falsa. Nesta, uma montagem, a pessoa era colocada em um parque de diversões onde nunca esteve. Oitenta por cento dos participantes reconheceram a imagem como legítima; os outros, que inicialmente não reconheceram a foto, ao serem questionados pelos pesquisadores, se lembraram da imagem, dizendo ter sido um dia mara- 
vilhoso com os pais: lembraram de uma memória falsa, fabricada - pela imaginação.

Estudos recentes da neurociência aventam a hipótese de que o hipocampo, a área do cérebro que tem papel indispensável para a formação e o armazenamento das memórias, também seria ativado quando construímos imagens do futuro. Em uma pesquisa liderada pela cientista Eleanor Maguire, cinco pacientes com amnésia, que haviam sofrido lesões no hipocampo, foram submetidos a testes comparativos com outras dez pessoas saudáveis, que serviram como grupo-controle, com idades e níveis educacionais semelhantes aos dos pacientes. Os 15 participantes descreveram experiências casuais da vida cotidiana: o encontro com um amigo, um passeio na praia, uma ida ao supermercado ou a um bar etc.

As descrições dos membros do grupo-controle eram ricas em detalhes: o cheiro do bar, o barulho do mar, a areia quente embaixo dos pés; os portadores de amnésia fizeram descrições mais pobres, com menos objetos e detalhes. "Isso sugere que o hipocampo seja mais versátil do que se imaginava: é uma estrutura fundamental para programar reconstruções vivas do passado, construir cenas futuras e eventos imaginários" (Varella, 2007).

Beatriz Sarlo, por sua vez, reitera que sempre há um vazio entre a lembrança e aquilo que se lembra, e esse vazio "é ocupado por operações linguísticas, discursivas, subjetivas e sociais do relato da memória" (Sarlo, 2005, p.99).

Essas teses sustentam o episódio narrado em Valsa com Bashir, e é o que parece acontecer, também, em A caixa de areia ou eu era dois em quintal: os brinquedos existiram; como foram perdidos (no quintal de casa ou na praia) e como reapareceram quase 40 anos depois é um artifício da imaginação sobre a memória. Conforme diz Albert Manguel, "imaginamos (ou sonhamos, inventamos, repetimos) histórias que nos permitem encenar e registrar processos de aprendizado de que talvez nem sequer tenhamos consciência integral, num vaivém contínuo entre o que acontece no mundo e o que fazemos de conta que acontece" (Manguel, 2008, p. 78). De uma forma ou de outra, a irrupção dos brinquedos da infância no cotidiano do Mutarelli-personagem é um desencadeador de seus questionamentos sobre a realidade, mas também sobre si próprio. Afinal, o eu é justamente "essa valiosa acumulação de lembranças da história pessoal, que constituem aquele passado com uma dimensão semântica onde tudo significa alguma coisa e cada peça é relevante para a complexa edificação do que se é" (Sibilia, 2008, p. 128). O significado de cada um dos brinquedos e também seu súbito reaparecimento anos depois guardam a chave para o entendimento da própria subjetividade do personagem. 
Pedro Galas Araújo

Pierre Nora pensa de modo semelhante a Huyssen e Sarlo, mas vai ainda mais longe. $\mathrm{O}$ autor chama a atenção para a transição da memória para a história em uma época que perdeu o sentimento de continuidade. Segundo ele, a aceleração do tempo provocou não só um senso de descontinuidade em relação ao passado e ao futuro, mas levou também a uma perda de memória: "Se habitássemos ainda nossa memória, não haveria a necessidade de lhe consagrar lugares", diz (Nora, 1993, p. 8). O historiador francês opõe memória e história como categorias distintas: a primeira é afetiva, mágica; a segunda exige análise e crítica; "a memória se enraíza no concreto, no espaço, no gesto, na imagem, no objeto. A história só se liga às continuidades temporais, às evoluções e às relações das coisas. A memória é um absoluto e a história só conhece o relativo" (id., p. 9).

O que acontece, segundo Nora, é que não há mais memória: associada ao rito, à tradição, aos costumes, ela não resiste às investidas do tempo, da novidade e da impossibilidade de uma memória total, e perde seu caráter sacro. Como espaço de afetos, ela se oblitera. Daí que ela ressurja como história, liberta, prosaica, vista como objeto de análise, de crítica, de revisão, e não de adoração. A memória segmenta, particulariza; a história unifica. Vivemos em um momento "onde desaparece um imenso capital que nós vivíamos na intimidade de uma memória, para só viver sob o olhar de uma história reconstituída" (id., p. 12).

Isso leva a um desejo de memória: de novo, algo que nos dê um sentido de continuidade, de permanência. No fundo, "a necessidade de memória e uma necessidade de história", diz Nora (id., p. 14). Daí que o autor afirme que, não tendo mais memória, e sendo a história tão distante e fria, porque nega sinais de reconhecimento e pertencimento, o indivíduo erija "lugares de memória", espaços onde história e memória, combinadas, permitam tanto o sentido de identidade quanto o de permanência: "o sentimento de continuidade torna-se residual nos locais", diz (id., p. 7).

Segundo Nora, "os lugares de memória nascem e vivem do sentimento que não há memória espontânea, que é preciso criar arquivos, que é preciso manter aniversários, organizar celebrações, pronunciar elogios fúnebres, notariar atas, porque essas operações não são naturais":

Museus, arquivos, cemitérios e coleções, festas, aniversários, tratados, processos verbais, monumentos, santuários, associações, são os marcos testemunhas de uma outra era, das ilusões de eternidade. Daí o aspecto nostálgico desses empreendimentos de piedade, patéticos e glaciais. São os rituais de uma sociedade sem ritual. (id., p. 13) 
Os brinquedos de Mutarelli parecem ser um desses "lugares de memória": preservam o sentimento de continuidade, oferecem uma explicação razoável para justificar quem ele mesmo é, sustentam um refúgio, são uma guarida frente ao caos do cotidiano e do presente, onde não há explicação alguma. Que o sonho de Borges também seja um, apesar de menos palpável ainda que os brinquedos de Mutarelli, não é de se estranhar: o sonho é o único espaço - pessoal, afetivo, próprio - onde se encontra consigo mesmo e recebe, apesar de contrariado, a explicação do porquê ser como é - apesar de que, neste caso, o que parece restar para Borges é uma pergunta nostálgica: "Como pude ser assim?", ao passo que o outro perguntaria: "Como pude me tornar isso?".

Em A caixa de areia ou eu era dois em meu quintal, além dessas questões, o leitor é apresentado, em paralelo à narrativa principal, a dois personagens, Carlton e Kleiton, enclausurados dentro de um automóvel que não vai a lugar nenhum: com os pneus arriados, está ilhado no deserto, sem rumo possível (fig. 4). Não fosse a diferença de nomes, seria possível dizer que são a mesma pessoa, apesar do contraste físico: um é gordo, o outro é magro, mas usam roupas semelhantes, têm o cabelo parecido e possuem o mesmo nariz avantajado, comprido, grotesco, irreal. Gastam o tempo conversando sobre o passado, um ouvindo do outro histórias fantasiosas de glórias antigas.

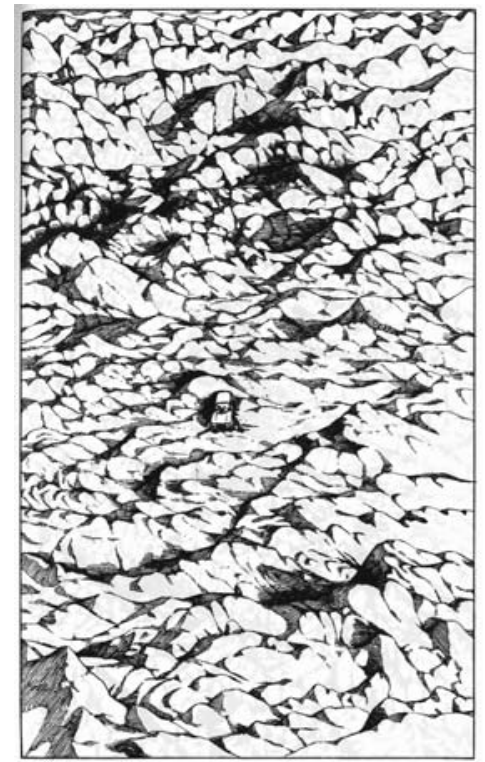

Fig. 4. Mutarelli. A caixa de areia ou eu era dois em meu quintal, p. 37. 
Aí começam as semelhanças e o ponto de contato entre essa narrativa e a principal, de Mutarelli e sua família: as histórias contadas por Carlton são também reinvenções do passado. O personagem se lembra do encontro com uma antiga namorada, "Hantuérpia", 30 anos depois de o relacionamento ter acabado. Em sua lembrança estava gravada a imagem antiga, "congelada", "suspensa" da moça. Conforme diz, ele havia esquecido de "computar-lhe esses trinta anos" (Mutarelli, 2005, p. 32). Por causa do carinho, manteve-a protegida das investidas do tempo, mas o choque entre a imagem anterior e a realidade do presente é avassalador: a lembrança afetiva e, portanto, idealizada, se dissipa, se desfaz, e toma seu lugar a imagem atual, com algum resquício do passado, mas sempre maculando, de alguma forma, aquilo que se tinha preservado na memória afetiva. No entanto, a própria Hantuérpia revela a Carlton que o tempo também não o poupou: "Você parece um pinguim", disse ela, segundo Carlton, ao que Kleiton o corrige: “Acho que ela quis dizer ' $\mathrm{O}$ ' Pinguim. Você parece 'O' Pinguim" (id., p. 35), numa alusão a um personagem das histórias em quadrinhos do Batman, o que reforça a patética decrepitude de Carlton. Como acontece com Mutarelli, é a lembrança transformada pelo sentimento que é preservada, ou seja, ela é parcial, interessada, a um só tempo irreal e nebulosa, e não objetiva.

Em um dado momento, mais adiante na narrativa, Carlton se transforma no "Capitão Idealidade", um super-herói meio ridículo que tem como adversária... a realidade. O combate acontece no vazio, com o herói desferindo dramaticamente golpes no ar até cair, exausto, sobre o carro imóvel no deserto. Durante os quadros da luta, o texto do quadrinho descreve o embate em tom filosófico: "Procura escapar àquilo que é e modificar-se, de tal maneira que aquilo que é, sem deixar de ter existido, possa revelarse, contudo, como termo de uma relação" (fig. 5), ou "Procura escapar, por negação interna, aos 'istos'-no-meio-do-mundo que não é pelos quais anuncia a si mesmo aquilo que é" (id., p. 92). 


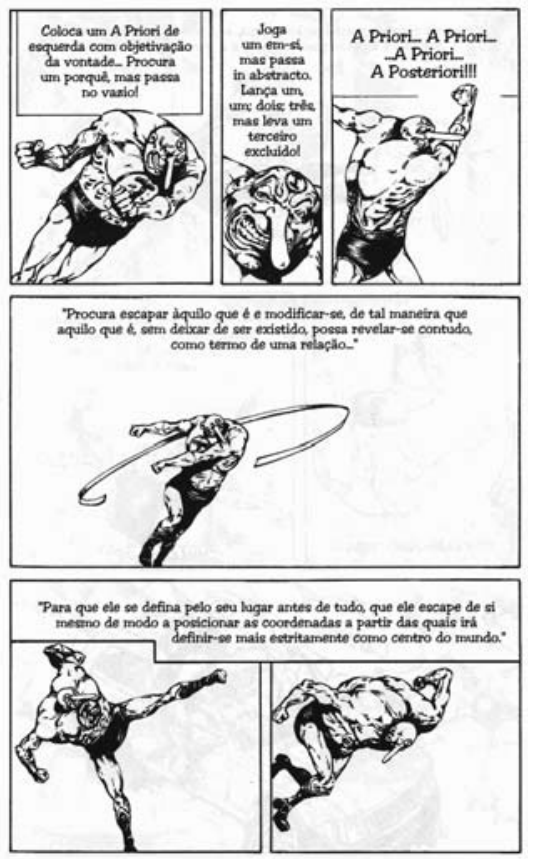

Fig. 5. Mutarelli. A caixa de areia ou eu era dois em meu quintal, p. 91.

A luta está inserida em outro universo, mas a relação estabelecida também se aplica ao conflito de Mutarelli no "mundo real": quem é, quem foi, quem poderia ter sido, e de que maneira o passado, representado na figura dos soldadinhos de plástico, o moldou e o definiu tal como é hoje. Sem ser possível afirmar nada sobre isso, só lhe resta reconhecer que "sua" história não existe de modo independente: é o próprio indivíduo quem a cria, quem a inventa para dar-lhe sentido.

Essa conexão entre as duas narrativas paralelas será reforçada, mais tarde, quase ao fim da obra, quando Carlton e Kleiton estão discutindo sobre qual história contar agora, e optam pela do "desenhista que encontrava seus brinquedos na caixa de areia" (id., p. 139). A autorreferência ao livro, a metalinguagem, aqui, desestabiliza de vez a ilusão, já anunciada antes pelo próprio Mutarelli-personagem, do "eu": ele não passava de um sonho, uma ideia, uma história contada por dois outros personagens - que, por sua vez, são invenções do desenhista. Daí o "eu era dois em meu quintal" do título. O que aconteceria com cada um deles se subitamente o outro parasse de pensá-los, de desenhá-los, de recriá-los com o anteparo indispensável da ficção? A alusão ao Rei Vermelho de Alice no 
país das maravilhas, páginas antes, não é gratuita: se o rei acorda, Alice, que não passava de um sonho dele, desapareceria. Como em "O outro", de Borges, o sonho de um sobre o outro possibilita o contato e o embate, mas, terminado, o que resulta daí é o desaparecimento de um ou do outro - do conflito entre passado e presente, qual dos dois prevalece? Da luta entre idealidade e realidade, quem sai vencedora?

Mas há outro ponto em que as narrativas se cruzam: o deserto, que é também a areia da caixa do gato. O que, mais uma vez, recoloca a questão: quem imaginou quem? Os dois no carro fantasiaram Mutarelli, ou o autor os inventou?

De uma forma ou de outra, é a areia o elemento comum entre as duas histórias, e sua associação com a memória está clara: "A areia do deserto guarda a forma de quem nela se deitar", está dito em uma das primeiras páginas do livro (id., p. 17). Na seguinte, a afirmação é completada: "A areia também guarda o que já não existe mais" (id., p. 18). A relação da areia com o tempo fica ainda mais clara quando, páginas depois, surge uma ampulheta na narrativa. "É como se o tempo só existisse quando tentamos medi-lo", diz Mutarelli (id., p. 42). Neste ponto, outro texto de Borges também enriquece o debate. Em O livro de areia, um dos objetos impossíveis do autor aparece: um livro infinito, sem começo nem fim, no qual não é possível perceber nem a primeira nem a última página. $\mathrm{O}$ narrador o obtém em uma negociação com um vendedor de bíblias que repentinamente - à maneira dos brinquedos de Mutarelli e do sonho do Borges-narrador em "O outro" - aparece à sua porta. Ainda que aparentemente relutante, o vendedor aceita a troca de O livro de areia por uma rara edição da bíblia, junto com o dinheiro da aposentadoria do narrador. "Assombrou-me que não regateasse. Só depois compreenderia que ele havia entrado em minha casa com a decisão de vender o livro", diz o narrador (Borges, 2001, p. 115). Fascinado com o livro, na primeira noite não consegue dormir. A isto segue-se o isolamento, provocado pela insegurança e pelo ciúme do objeto, mas também pelo deslumbramento que provoca. "Prisioneiro do Livro, quase não assomava à rua", diz (id., p. 115). Por fim, o narrador percebe que o livro era monstruoso, diabólico, "um objeto de pesadelo, uma coisa obscena que infamava e corrompia a realidade" (id., p. 116), e dá cabo do livro, perdendo-o entre as prateleiras de uma vasta biblioteca, a qual nunca mais visitou.

A referência ao amor pela literatura e às possibilidades da leitura (ou ao perigo dos livros?), por mais clara que seja, mascara outra possível interpretação: O livro de areia, enciclopédico que é, aparentemente um enorme catálogo, comparado com uma bíblia e com um dicionário pelo 
narrador, representa também a memória. Sendo infinito, deve guardar tudo o que existe no universo. Mas, como no caso de Funes, também ele, como uma memória eterna e infalível, leva à loucura: a curiosidade que gera o isolamento e a insônia do narrador.

De novo, a memória total não concede descanso; na verdade, adoece o sujeito. É preciso esquecer, para prosseguir. É preciso se distanciar do passado para mover-se propriamente pelo presente. Como no caso de $A$ caixa de areia ou eu era dois em quintal, a lembrança é uma trava que atormenta, porque aprisiona. Por outro lado, é por meio dela que se pode compreender o presente e se dirigir ao futuro. "Somos aquilo de que nos lembramos", disse certa vez Norberto Bobbio, ao que acrescentaríamos, com Iván Izquierdo: "Somos aquilo que conseguimos lembrar", mas "somos também aquilo que decidimos esquecer" (Izquierdo, 2004, p. 110).

\section{Referências bibliográficas}

BORGES, Jorge Luis (1998). Obras completas. v. 1. São Paulo: Globo. (2001). O livro de areia. São Paulo: Globo.

HUYSSEN, Andreas (2000). Seduzidos pela memória: arquitetura, monumentos, mídia. Rio de Janeiro: Aeroplano.

IZQUIERDO, Iván (2004). A arte de esquecer: cérebro, memória e esquecimento. Rio de Janeiro: Vieira \& Lent.

LEJEUNE, Philippe (2008). O pacto autobiográfico. Belo Horizonte: Editora UFMG.

MANGUEL, Albert (2008). A cidade das palavras. São Paulo: Companhia das Letras.

MUTARELLI, Lourenço (2005). A caixa de areia ou eu era dois em meu quintal. São Paulo: Devir.

NORA, Pierre (1993). “Entre Memória e História: a problemática dos lugares". In: Projeto História. São Paulo: PUC. n. 10, p. 7-28, dezembro.

SARLO, Beatriz (2005). Tempo presente: notas sobre a mudança de uma cultura. Rio de Janeiro: José Olympio.

SARLO, Beatriz (2007). Tempo passado: cultura da memória e guinada subjetiva. São Paulo: Companhia das Letras; Belo Horizonte: UFMG.

SELIGMANN-SILVA, Márcio (2005). O local da diferença. São Paulo: Ed. 34.

SIBILIA, Paula (2008). O show do eu: a intimidade como espetáculo. Rio de Janeiro: Nova Fronteira.

VARELLA, Drauzio (2007). "Memória e imaginação". Disponível em: <http:/ / www.drauziovarella.com.br/ExibirConteudo/5014/memoria-e-imaginacao >. 
Pedro Galas Araújo

Recebido em julho de 2010.

Aprovado para publicação em janeiro de 2011.

\section{resumolabstract}

Memórias fraturadas: passado, identidade e imaginação em Borges e Mutarelli

Pedro Galas Araújo

A memória constitui a identidade de uma coletividade e também a do indivíduo: é a partir dela que construímos a narrativa que organiza nossa subjetividade. No entanto, ela é falha, omissa, conveniente. Como é possível, então, ter a identidade alicerçada em terreno tão movediço? Ainda assim, as últimas décadas do século XX foram marcadas pelo que Andreas Huyssen chamou de "cultura da memória": uma valorização do passado como elemento que dá coerência à nossa própria experiência, em oposição a um presente fraturado em instantes, que não nos oferece nenhum vislumbre de um futuro promissor. Este trabalho procura discutir tal questão a partir do diálogo entre os contos "O outro" e "Funes, o memorioso", de Jorge Luis Borges, e a narrativa em quadrinhos A caixa de areia ou eu era dois em meu quintal, de Lourenço Mutarelli, incluindo aspectos como a construção da identidade e o recurso à imaginação nessa operação.

Palavras-chave: memória, identidade, imaginação, Jorge Luis Borges, Lourenço Mutarelli

\section{Fractured memories, past, identity and imagination in Borges and Mutarelli}

Pedro Galas Araújo

Memory forms the identity of a collectivity as well as that of the individual: it is the point from which we construct a narrative that organizes our subjectivity. However, it is defective, lacking, accomodating. How can we thus have the identity built upon such unstable ground? Still, the last decades of the twentieth century were marked by what Andreas Huyssen calls of "culture of memory": an appreciation of the past as an element that gives coherence to our own experience, as opposed to a fractured present, which offers no glimpse of a promising future. This paper discusses such issues through the dialogue between the stories "O outro" and "Funes, o memorioso", by Jorge Luis Borges, and the comics narrative "A caixa de areia ou eu era dois em meu quintal" by Lourenço Mutarelli, including aspects such as identity construction and the use of imagination in that operation.

Key words: memory, self, imagination, Jorge Luis Borges, Lourenço Mutarelli

Pedro Galas Araújo - “Memórias fraturadas: passado, identidade e imaginação em Borges e Mutarelli". Estudos de Literatura Brasileira Contemporânea, n. 37. Brasília, janeiro-junho de 2011, p. 123-140. 